\title{
Lost Autonomy, Nationalism and Separatism
}

\section{David S. Siroky ${ }^{1}$ and John Cuffe ${ }^{2}$}

\begin{abstract}
Case studies suggest that ethnic groups with autonomous institutional arrangements are more prone to secede, but other evidence indicates that autonomy reduces the likelihood of secession. To address this debate, we disaggregate their autonomy status into three categoriescurrently autonomous, never autonomous, and lost autonomy-and then unpack how each shapes the logic of collective action. We argue groups that were never autonomous are unlikely to mobilize due to a lack of collective action capacity, whereas currently autonomous groups may have the capacity but often lack the motivation. Most important, groups that have lost autonomy often possess both strong incentives and the capacity to pursue secession, which facilitates collective action. Moreover, autonomy retraction weakens the government's ability to make future credible commitments to redress grievances. We test these conjectures with data on the autonomous status and separatist behavior of 324 groups in more than 100 countries from 1960 to 2000. Our analysis shows clear empirical results regarding the relationship between autonomy status and separatism. Most notably, we find that formerly autonomous groups are the most likely to secede, and that both currently autonomous and never autonomous groups are much less likely.
\end{abstract}

\section{Keywords}

nationalism, separatism, decentralization, autonomy

Does autonomy satisfy the demand for more self-determination, or instead foster the capacity and whet the appetite for independence? Is political

\footnotetext{
${ }^{1}$ Arizona State University, Tempe, USA

${ }^{2}$ University of California, Irvine, USA
}

\section{Corresponding Author:}

David S. Siroky, School of Politics and Global Studies, Arizona State University, P.O. Box 873902, Tempe, AZ 85287-3902, USA.

Email: david.siroky@asu.edu 
decentralization a viable solution for multiethnic states, or a slippery slope? Some scholars and policymakers see autonomy as the main mechanism to resolve tensions and redistributive issues between the central government and spatially concentrated, culturally distinct groups (Bermeo, 2002; Bermeo \& Amoretti, 2003; L. Diamond, 1999; Stepan, 1999). Others studies, however, show that autonomy can actually exacerbate relations between the state and ethnic groups, for it cultivates the capacity for collective action and self-rule without significantly reducing desire for more of it (Brancati, 2009; Bunce, 1999; Coppieters, 2001; Cornell, 2002; Roeder, 1991).

This article posits that the theoretical and empirical disagreement over the effect of autonomy is partly due to conflating two distinct situations in the implicit reference category-groups that are not autonomous. This binary classification compares groups that are currently autonomous to a baseline that is comprised of both groups that have never been autonomous, and those that once had autonomy, but lost it. Groups that have never been autonomous and those that have lost autonomy are distinct in their motivation and their capacity for collective action. Whereas never autonomous groups may be unlikely to mobilize due to a lack of collective action capacity, currently autonomous groups may have such capacity, but should find the cost of attempting to alter the status quo too high compared with the benefits they currently enjoy from being autonomous. Most important, we argue that groups which have lost autonomy possess both powerful incentives in the form of grievances and often also have the capacity for collective action capacity, which leads us to expect such groups to be more likely to pursue secession.

Following previous studies, we define autonomy as a form of internal selfdetermination that provides a group with actual powers and resources for self-governance within a state (Brancati, 2009; Wolff, 2013; Zinn, 2006). ${ }^{1}$ Specifically, we build on Wolff's (2013) definition of "territorial selfgovernance," which he describes as "legally entrenched power of territorially-delimited entities within the internationally recognized boundaries of existing states to exercise public policy functions independently of other sources of authority in this state, but subject to its overall legal order" (p. 5). To this definition, we add Stepan's (1999) of asymmetric arrangements, meaning that the powers devolved to a group must not apply for all of the groups within the state. For example, the United States has symmetric federal arrangements - in theory, states are all treated equally relative to the central government. In other countries, such as Spain, Indonesia, and Canada, particular regions are granted asymmetric autonomous arrangements above and beyond what other regions within the state possess. For example, the government in Catalonia in Spain, currently 
headed by a regionalist-nationalist party (Convergència Democràtica de Catalunya, the CDC), possesses high levels of formal autonomy through the constitution and high levels of control over the day-to-day affairs within the province. $^{2}$ As a result, Catalonia is coded as currently autonomous.

We do not blindly follow formal laws, however, but also consider the degree of de facto autonomy (especially in autocracies) in determining whether to code a case as autonomous. For example, although Tibet is officially as an autonomous region in China, the Chinese government exerts considerable control over the Tibetan government, appoints administrators from foreign regions and directly selects its own Dalai Lama as an attempt to control Tibetan religious organizations, a key consideration considering the role of Monks in Tibetan society. We therefore code Tibet as having lost autonomy in $1949 .^{3}$

We argue that groups which have recently lost autonomy should be more likely to engage in separatism than groups that are currently autonomous or groups that were never autonomous, ceteris paribus. We hypothesize that lost autonomy increases the likelihood of separatism through four main mechanisms. First, it fosters ethnic resentment as a result of diminished status, which engenders grievances that are increasingly hard to appease (e.g., Petersen, 2002). Second, it weakens the central government's ability to make credible commitments, which reduces the viability of conciliatory political strategies (e.g., Hale, 2008a; Hale, 2008b).

Third, retracting autonomy does not necessarily curb the group's collective action capacity, which was gained and developed under autonomy, as leadership loss, generational replacement, and assimilation are relatively slow processes (Siroky and Aprasdize, 2011). Finally, while the free rider problem is widely recognized, we suggest that the cost of free riding within a group that recently lost autonomy may be higher than joining forces with those who seek separation (Hechter, 2000; Kalyvas \& Kocher, 2007), thus making lost autonomy a particularly powerful basis for secession. Currently autonomous groups must weigh the potential loss of their current status against their unrealized desire for full independence, and we therefore predict that they should be less prone to secession than those that recently lost autonomy.

We develop this logic and derive several key empirical implications in the next section. Using a data set that builds on the latest data sources on ethnic politics and conflict, and covers roughly 330 ethnically distinct groups in more than 110 states over a 40-year period, our analysis indicates that formerly autonomous groups are the most likely to secede, whereas currently autonomous and never autonomous groups were significantly less likely to do so. These results provide strong evidence regarding the impact of lost autonomy on separatism, and are robust to matching on covariates, instrumental variables, different estimators, and confounding variables. ${ }^{4} \mathrm{We}$ also find, in most models, that currently autonomous have a higher propensity 
for separatism than groups that have never been autonomous. The results shed new light on existing empirical results, and contribute to the longstanding debate regarding the relationship between autonomy and separatism. The final section discusses potential implications of this study for the design of institutions in multiethnic countries and proposes several directions for future research.

\section{A Theory of Lost Autonomy}

We situate our contribution within the context of debates over the effect of decentralized institutions - specifically, the effect of regional autonomy-on nationalist mobilization and separatism (Bunce, 1999; Hale, 2000; Hechter \& Okamoto, 2001; Horowitz, 1985; Kymlicka, 2008; Miodownik \& Cartrite, 2010; Rogowski, 1985; Sambanis \& Zinn, 2005; Treisman, 1997). Proponents of autonomous institutional arrangements argue that political decentralization is the primary means by which a large multiethnic state can relieve ethno-regional tensions on its periphery and preserve a unified polity (Brass, 1991; Gurr, 2000; Kaufman, 1996; Lijphart, 1977; McGarry \& O'Leary, 1993; Stepan, 1999; Tsebelis, 1990). The language of selfdetermination and minority rights, which was originally used by the Great Powers to redraw boundaries after World War I, and later used to justify the process of decolonization, has been increasingly utilized by ethnic minority groups, which have wielded it effectively to extract concessions from the central government (Jenne, 2007; Jenne, 2010).

Most recently, decentralization of power to ethnic regions has been touted as a potential solution to tensions with ethnic minority groups in Iraq and Afghanistan (O'Hanlon \& Joseph, 2007), and has been discussed in many other hot spot regions around the world, including the Balkans (Guss \& Siroky, 2012), Ethiopia (Ghai, 2000), and other parts of sub-Saharan Africa (Forrest, 2004). Many studies have shown that autonomy bears a strong relationship to peace in the developed world (e.g., Spain, Germany, the United States, Switzerland, Australia) and in the developing world (e.g., Nigeria, India, Mexico, Ethiopia). Autonomy "has done more to relieve or contain secessionist pressures," wrote Larry Diamond (1999), "than to stimulate them" (p. 156). Stepan (1999) reinforces this point when he notes that "every single longstanding democracy in a multilingual and multinational polity is a federal state" (p. 19).

Decentralization as an approach to ethnic conflict management is certainly not without its detractors, who argue that centrifugal concessions to ethnic groups create a "slippery slope" of increasing demands for selfdetermination. Autonomy is unlikely to satisfy a group's demands for self- 
rule, in this view, and is much more likely to reinforce ethnic particularism and prejudices by providing group leaders with the symbolic and material resources needed to mobilize co-ethnics against the state (Ghai, 2000). This form of minority concession may also engender a strong political backlash (Bustikova, 2014). In short, scholars have argued that autonomy serves as the basis for secessionism by sharpening borders, "constructing" nations, and fostering centrifugal incentives among regional elites (Cornell, 2002; Slezkine, 1994; Streat-Bartlett, 2009).

If there is a consensus in this literature, then it can only be that the net impact of autonomy is mixed, contingent on other factors, for example, the strength of regional parties, the existence of prior conflicts, the level of development, the wider geopolitical environment, and so on (Brancati, 2009; Jenne, 2010). It would appear that autonomy has no consistent empirical relationship with separatist activity, even though there is case study evidence to support arguments both in favor and against it (Cornell, 2002; Roeder, 1991; Stepan, 1999). In short, the empirical record remains "murky" (Hechter \& Okamoto, 2001), and we aim to provide some conceptual and empirical clarity regarding the relationship between autonomy and separatism.

We suggest that to advance this debate it is crucial to disaggregate the implicit baseline of comparison-"non-autonomous status." A binary (autonomous or not) framing of the debate over the effect of autonomy masks two distinct scenarios: one in which an ethnic group has never been autonomous, and another in which an ethnic group lost their autonomy. Although both are technically not autonomous, we predict that one group (lost autonomy) is highly prone to separatism, whereas the other group (never autonomous) is very unlikely to pursue secession, because on average they lack both the leadership and grievances required for collective action (Saxton, 2005).

By contrast, currently autonomous groups are more likely to have the capacity to overcome collective action problems. The capacity for separatism is largely irrelevant, however, if autonomous groups lack the desire for secession, either because the status quo satisfies their demand for selfdetermination or the potential risks associated with rebellion are excessively great. Most important, we predict the greatest amount of separatist activity from groups that were recently deprived of autonomy-those groups that experienced a shift from indirect rule to direct rule (Hechter, 2013; Siroky and Aprasdize, 2011; Siroky, Dzutsev, \& Hechter, 2013). Retracted or lost autonomy provides a strong motive and need not significantly diminish the group's collective action capacity. Moreover, it considerably weakens the government's ability to make credible commitments that might otherwise prevent tensions from escalating, making "voice" seem less likely to yield positive results than exit, thereby increasing the probability of secession (Hirschman, 1970; North \& Weingast, 1989; Siroky and Aprasdize, 2011). 
Lost autonomy is not a new idea in political science. Gurr (1993) and Gurr and Moore (1997), for example, both emphasized the impact of lost autonomy on rebellion. Our approach builds on this earlier literature and extends it in two key ways. First, rather than comparing groups that have lost autonomy to all other groups, we distinguish and disaggregate between groups that have never been autonomous, groups that are currently autonomous and groups that have lost autonomy. This conceptualization, we suggest, offers better traction on the relationship between autonomy and separatism than a binary classification. Second, we hypothesize that lost autonomy engenders resentment, which increases the group's grievances, reduces the government's capacity to make future credible commitments that might bring cooler heads and calmer voices to the fore, and does not necessarily reduce the collective action capacities and advantages that groups gained during autonomy (i.e., leaders, elite networks, and administrative experience). Autonomy retraction may also decrease a group's collective action problems by increasing the cost of free riding relative to participation (Kalyvas \& Kocher, 2007). ${ }^{5}$ In sum, we argue that lost autonomy enhances both the motives and the capacities for collective action, and reduces the government's ability to extend incentives and attract moderates. This makes such groups (in the grey shaded box, Table 1) more likely to pursue secession than those groups with no history of autonomy and those that are currently autonomous (in the unshaded boxes, Table 1). This leads us to derive two main hypotheses:

Hypothesis 1: Groups that have lost autonomy are more likely to pursue separatism than currently autonomous groups.

Hypothesis 2: Currently autonomous groups are more likely to pursue separatism than groups with no history of autonomy.

Before we test these hypotheses more rigorously, we first explore their plausibility with four cases from distinct regions-Eastern Europe, East Asia, South Asia, and sub-Saharan Africa. These illustrative vignettes highlight the process of secession following the loss of autonomy, which we contrast against the group's behavior during and before autonomy, as a means to examine how well the causal mechanisms operate across several geographically diverse settings, and to complement the quantitative analysis that follows.

Table 1.Theoretical Expectations. 


\begin{tabular}{|c|c|c|}
\hline & Low capacity & High capacity \\
\hline Weak motives & $\begin{array}{l}\text { Never autonomous, } \\
\text { included groups }\end{array}$ & Currently autonomous groups \\
\hline Strong motive & $\begin{array}{r}\text { Never autonomous, } \\
\text { excluded groups }\end{array}$ & $\begin{array}{c}\text { Historically autonomous groups } \\
\text { (Separatism most likely) }\end{array}$ \\
\hline
\end{tabular}

\section{Four Vignettes}

\section{Kosovo's Secession}

Ethnic Albanians in Kosovo were granted special considerations under the 1946 Constitution, and were later granted full autonomy as a province (Autonomna Pokrajina) in 1974 (Kubo, 2011). However, this situation was quickly reversed in 1990, when the region effectively returned to its pre-1974 status. Slobodan Milosevic's increasing power within the quickly fragmenting Yugoslavia, along with the local government's discriminatory policies toward ethnic Serbians (McGwire, 2000), led to public resentment over the perceived "extremity" of Kosovo's autonomy within Yugoslavia (Petersen, 2002), and soon resulted in the formal revocation of Kosovo's autonomy in 1990 through constitutional changes (Silber, Little, \& British Broadcast Corporation, 1996; Zimmermann, 1999). These changes included abolishing Kosovo's official public media, transferring control over stateowned companies to Belgrade, and replacing Albanian educational textbooks and education in the Albanian language at Pristina University. Not surprisingly, the revocation of autonomy led to reciprocal resentment among the ethnic Albanians within Kosovo. Grievances escalated on both sides, and so did collective action. On the Albanian side, the organizational structures developed during their period of autonomy were still largely in tact, and played a crucial role in their subsequent mobilization and eventual militarization.

Two factions emerged to represent the Kosovar Albanian case: Ibrahim Rugova led the first group highlighting Kosovo's distinct ethnic identity and heritage in ancient Dardania, a once independent kingdom and later a Roman province, through nonviolent means, especially in schools and cultural centers (Pula, 2004). The second faction, which came to be known as the Kosovo Liberation Army (KLA or UÇK), pursued a more radical approach, and launched attacks against Yugoslav officials and police stations (Agence France Presse, 1995). Tired of Rugova's approach, the KLA argued that negotiations had failed, and that a more aggressive line of attack would prove more effective. The KLA's approach gained popularity among Kosovars, and the recruitment of volunteers as well as funding from abroad for the "national cause" increased between 1996 (the KLA's first formal attack against Yugoslav authorities) and 1999 (the year of NATO's intervention through Operation Allied Force; Judah, 2002, p. 805; Pula, 2004). 
While revoking autonomy may have quelled discontent among Serbs in Kosovo, it increased grievances among the majority of Albanians in Kosovo. Even those individuals not directly demoted or replaced joined others in solidarity by engaging in civil disobedience (Clark, 2000). The structures, including many of the top leaders and key organizations, carried over from the period of autonomy and played a crucial role in Rugova's nonviolent movement for self-rule, and the KLA's ability to recruit and mobilize for independence. Although the full story of Kosovo's drive for secession is beyond the scope of this narrative, the key elements highlighted here-the increased salience of grievances, the leadership, and the collective action capacity - were a direct result of the decision to revoke Kosovo's autonomy in 1990. NATO's intervention and other foreign support played a crucial role in the ultimate success of the KLA, but the initial impetus was largely internal. Lost autonomy stimulated popular discontent and served to make secession, which had led to outright war in Bosnia and Croatia and was thus risky, into an increasingly attractive alternative to continued negotiations with Belgrade (Costalli \& Moro, 2012).

\section{South Sudanese Separatism}

The impact of lost autonomy on separatism is also evident in Sudan. Culturally distinct Southerners resented the Arabic North for the slave trade (Deng, 2006), "political marginalization, economic neglect, and cultural domination" (Lado, 2002, p. 159). The Addis Abba Accords ended the first Sudanese Civil War and granted regional autonomy to the South in 1974 (Beshir, Mohammad-Salih, \& Abdul-Jalil, 1984; Eprile, 1974), which initially showed some promise of reducing tensions. Over time, however, increasingly Islamic policies in the North resulted in a new Constitution in 1983, which severely reduced the South's autonomy, both politically by fragmenting the South into subunits (Salih, 1994) and culturally by instituting Islamic policies (Beshir et al., 1984). Between 1980 and 1983, the North seized several oil fields in the South, which exacerbated tensions and increased the South's incentives to pursue its own independence. ${ }^{6}$

The combination of political, economic, and cultural grievances let to the formation of an opposition Southern People's Liberation Movement/Army under the leadership of former national cabinet member John Garang. The organization initially had the support of several international organizations (Adar, 1998) and of Ethiopia (Kebbede, 1997b). The removal of Northern President Nimeiri, due to backlash over drought, provided hope for a peaceful solution. In 1989, however, the National Islamic Front gained power in the 
North (Kebbede, 1997b), rescinding many of the promises made to the South and intensifying the conflict.

Despite several internal divisions, the SPLA (Sudan People's Liberation Army) maintained an almost 30-year long separatist movement, which eventually led to secession (Kebbede, 1997a). The movement for Southern Sudan used the retraction of autonomy to powerful effect. While heterogeneous and sometimes rival ethnic groups vied for power within the movement, its focal point - a sense of cultural imperialism-sustained it. Moreover, leadership experience gained during the period of autonomy, along with experience gained from the regional legislative assembly, served the movement well in overcoming the collective action problem required for the secessionist movement to survive and ultimately to become the newest member of the United Nations.

\section{Tibetan Separatism in China}

Chinese forces invaded Tibet following the Communist takeover of mainland China. Although officially listed as an autonomous region, this autonomy exists largely as a façade. Beijing maintains strict control over Tibet and retains the right to "approve" the next Dalai Lama as well as repeatedly attempting to monitor the activities of Tibetan monks (Teufel, 2005, p. 71). Despite an overwhelming military defeat, the Tibetan Government in Exile (TGE) that subsequently formed in India has successfully served as a rallying point for the independence of Tibet (Cunningham \& Beaulieu, 2010; Fuller, Morrison, Murphy, \& Ridley, 2002). For over half a century, since Tibet lost its autonomy, the TGE has facilitated collective action and provided Tibetans with a unified political voice to pursue greater autonomy and independence.

Formally and informally, Tibet lost its autonomy in 1949. Tibet subsequently launched and has maintained for more than 60 years a strong separatist movement (Sautman, 2005), even being characterized as China's "most rebellious" territory (Karmel, 1995). Although Tibet may have trouble overcoming Chinese rule and gaining independence due to China's military and economic superiority, Tibet has maintained its cohesion as a movement for many decades, and this resilience stems in part from its ability to rally supporters around the issue of its lost autonomy and the need for independence as the only means to preserve its distinct cultural identity.

Leadership experience gained when Tibet was autonomous has served the TGE in its difficult role of maintaining the movement over several decades and against a determined and strong state. Now based in northern India, the TGE as initially composed of former ministers who escaped the war and provided the leadership capacity to form and foster a coherent movement for independence. The Dalai Lama, a powerful cultural and spiritual symbol for Tibetans, is a carryover from the period of Tibetan autonomy. Until his retirement in 2011, he served as the head of state for the TGE after fleeing 
Tibet a decade after the initial invasion. Although his stance has softened on the best course of action for Tibet (He \& Sautman, 2005), the Tibetan leadership still insists Tibet and China do not share a common cultural identity, which serves as the basis for its claims to autonomy (Karmel, 1995). Even though Tibet is not economically-vital for China, holding firm demonstrates the regime's ability to resist international pressures (Gladney, 2003; Sautman, 1999; Walsh, 1993).

\section{Assamese Separatism in India}

A fully autonomous region during the first decades of Indian independence, the Assamese began to engage in separatist activity in earnest in the late 1970s following India's campaign of "internal colonialism" (Darnell \& Parikh, 1988; Hechter, 1975). The Indian central government had been progressively encroaching on the traditional homeland of the Assamese since the 1970s. Tensions between "Assamese regional patriotism and panIndianism" (Baruah, 2009, p. 953) escalated throughout the 1970s and 1980s (Gurr, 2009), especially during the 1983 local elections (Baruah, 2009; Dasgupta \& Guha, 1985), and came to a fountainhead following the formal retraction of autonomy in 1991 and the subsequent military operations (Misra, 1995).

Indian expansion into Assam had, over many years, engendered strong grievances toward the central government, and prompted some early signs of collective action (e.g., protests, strikes) and later led to calls for independence (Darnell \& Parikh, 1988). While Indian authorities have been able to arrest many individual operators of the United Front for the Liberation of Assam (UFLA), they have not removed "the soil that germinates the rebels" (Kalita, 2009, p. 102). The "soil" has two components that help to overcome the collective action problem: First, a strong sense of injustice at having their autonomy reduced and ultimately retracted, and second, the leadership and political capabilities developed during autonomy, first with the Movement for Assam in the late 1970s and then with the UFLA, and through ties to the former regional legislative assembly (Baruah, 2009). Both of these factors have combined to sustain the movement for an independent Assam, despite the overwhelming economic and military superiority of the Indian state, and continue to serve as the movement's focal point for mobilization.

\section{Summary of Vignettes}

Although these cases all take place at different times and on different continents, a key dynamic clearly emerges and illustrates how lost autonomy 
increased separatism relative both to the period during and prior to autonomy. The case studies also clearly establish that, after losing autonomy, the groups were struggling to move beyond autonomy, which was no longer credible, rather than to regain autonomous status. When the central authorities retracted autonomy from each of these groups (or full independence, in the case of Tibet), the ethnic groups all responded by mobilizing and engaging in sustained collective action to separate and establish an independent state. This mobilization was more sustained and significant than collective action during and before autonomy.

In Kosovo, the central government in Belgrade limited regional powers and replaced local leaders with Belgrade-backed candidates. This led to the "decisive protests" by Albanian workers that soon spread throughout the region (Pula, 2004, p. 803). In the Sudan, the government in Khartoum redrew the administrative lines of the South's autonomous region to control oil supplies (Bennett, 1987) and later abolished the local government (Kebbede, 1997a). This led to the formation of the South Sudanese Liberation Army and widespread violence that dwarfed the conflict during and before the period of autonomy, and ultimately resulted in a new state that has been universally recognized. In Assam, the central government in New Delhi first interfered directly into the economic affairs in the late 1970s and early 1980s, and then formally revoked the region's autonomy. This led to significant violence and collective action aimed at secession from India, whereas prior tensions had only been fully within the framework of autonomy.

In each case, revoking autonomy triggered collective action. If this relationship was endogenous - autonomy drove separatist collective action, which led to autonomy retraction, then groups that lost autonomy should be less separatist than groups that are currently autonomous, because the group has lost the capacity to secede that it enjoyed under autonomy. The evidence in these cases does not support this causal ordering, and instead indicates that the retraction of autonomy is what led to an increase in separatist activity rather than the reverse; the time period prior to autonomy appears to be most quiescent, and the period after lost autonomy the most likely to witness separatism.

Between 1974 and 1990, Kosovo was relatively peaceful (Malcom, 1998). Prior to Indian independence from Britain, Assam had no history of largescale rebellion (Sinha, 2007). Tibet was its own independent nation prior to the Chinese takeover, and thus could not exhibit separatism (Shakya, 1999). Although it is true that South Sudan was certainly not calm prior to gaining autonomy, it is clear that the period after autonomy was revoked generated a conflict of a different order, resulting in three times as many deaths and to the demand for separation of the South from the North (Biel, 2003; Kebbede, 1997b). Analyzing these cases from the perspective of autonomy status indicates that lost autonomy is significantly more likely to produce separatism than autonomy, and that the period prior to autonomy is the least 
likely to spawn separatism. While some of these cases exhibited disputes over status prior to the loss of autonomy, in all cases the revocation of autonomy escalated the group's demands, generated sustained separatist movements and resulted in widespread violence.

The next section analyzes how well the findings from these four cases generalize using newly disaggregated global data on autonomy and separatist activity.

\section{Data Description}

Our unit of analysis is the ethnic group-year within an individual state, measured every 5 years beginning in 1960 until 2000. This unit of analysis allows us to analyze the differential mobilization of the same group in different states. For example, using the research design, we are able to analyze why the Kurds have mobilized in Turkey and Iraq much more than in Iran and Syria. Moreover, the mechanisms that motivate the theoretical relationship between lost autonomy and separatism focus on the relationship between the ethnic group and the host state rather than on linkages across borders between groups that are nominally the same. Common ethnic ancestry does not necessarily imply cooperation across borders. Institutional differences between states, for instance, can drastically alter perceptions of ethnicity, the salience of cleavages and the demand for separatism. ${ }^{7}$ Most important, one state may change the autonomous status of an ethnic minority, while the other state does not, which would lead us to expect different group behavior and outcomes. For instance, the retraction of autonomy in South Ossetia (in Georgia) was not matched by the retraction of autonomy in North Ossetia (Russia), and the former mobilized for separatism, whereas the latter did not. The group-year-state research design allows us to capture these crucial differences that would be blurred if we were to use a more aggregated unit of analysis.

We built our data set drawing upon two primary sources. As our baseline, we used the Ethnic Power Relations (EPR) data set, ${ }^{8}$ and then added additional data from the Minorities at Risk (MAR) project. ${ }^{9}$ For groups that were omitted from the EPR and MAR data sets, or coded differently across the two data sources, we conducted our search to sort out discrepancies. When groups had the same name between MAR and EPR, the data were merged for every group-year. For groups that were not in both MAR and EPR, we determined whether one or the other data set: (1) had an exchangeable name for the same group, (2) had aggregated distinct groups into a larger category, or (3) had no equivalent in the other data set. In the case of (1), we simply renamed the group to ensure a match. In cases of (2), 
we used the more disaggregated data, and in cases of (3), we included the unmatched group in the new data set, and coded missing covariates using secondary sources, if possible.

Our dependent variable is constructed on the basis of MAR's Separatism Index, which we transformed from a 4-point unordered scale into a binary indicator of a sustained political movement for separatism on behalf of an ethnic group between 1960 and $2000 .{ }^{10}$ We also validated the coding of every case in terms of its formal loss of autonomy and the timing of separatism using qualitative data, and in most cases found that the coding from MAR and EPR were accurate. When we could not identify clear separatist movements, despite a civil war involving distinct ethnic groups, we adopted a conservative approach and coded the group as having no separatist movement. This was especially relevant in cases of revolutionary conflict in which the parties to the conflict could be distinguished by ethnicity (e.g., the Democratic Republic of Congo), but none of the groups sought to separate from the central state.

Our main independent variable is a trichotomous indicator of a group's autonomy status. We utilize Wolff's criteria for "territorial self-governance" with the qualification that the powers granted to groups must be asymmetric within a state. To operationalize this concept, we relied on several sources. If MAR's autonomy status indicator showed the group was autonomous in the given year, we coded this as autonomous, unless it did not possess de facto autonomy (e.g., Tibet). To distinguish between never autonomous groups and those who lost their autonomy, we used MAR's AUTLOST index. This index measures when, and to what degree, a group lost their autonomy. Any group who's AUTLOST score was equal to or greater than "1" and where a specific year of autonomy retraction was identified either through MAR's "autonend" variable, the MAR Qualitative data on the group and EPR's "demoted" variable - was coded as having lost autonomy. ${ }^{11}$ This triangulation of coding enables us to guarantee that we do not conflate any level of participation by the central state in a group's affairs as autonomy loss by supplementing the level of autonomy loss with an identifiable event such as an invasion or constitutional amendment.

In addition to the group's autonomy status, we also included data on several other relevant covariates. First, to control for differences across regime types, we include a trichotomous indicator of regime type (democracies, autocracies, and hybrid regimes), drawing on the expanded Polity 4 project data (Epstein, Bates, Goldstone, Kristensen, \& O’Halloran, 2006; K. S. Gleditsch, 2008). Second, we account for the state's exclusion of noncore ethnic groups from the political process using the EPR data (Cederman, Wimmer, \& Min, 2010; Wimmer, 2002), which has been shown to increase the likelihood of conflict (Wucherpfennig, Metternich, Cederman, \& Gleditsch, 2012). We argue that a similar mechanism occurs in the more specific case of separatism. As the number of politically excluded or 
vulnerable ethnic groups in a state increases, the likelihood of a group becoming separatist also increases. Third, we also include a measure of the group's spatial concentration based on MAR's 4-point ordinal scale GCON. If a group is highly concentrated, it is more likely to provide in-group social and economic services to its members, a key role that must be played by rebel organizations aiming at secession (Mampilly, 2011; Toft, 2003; Weidmann, 2009). ${ }^{12}$ We also account for the presence of oil on the group's territory as an indicator of economic viability and of the state's material interest in the region (Collier \& Hoeffler, 2004; Lujala, Rod, \& Thieme, 2007). We include a measure of external support for each ethnic group based data from Salehyan, Gleditsch, and Cunningham (2011) ${ }^{13}$ We also control for GDP per capita at the country level, which has been widely used as a proxy for state capacity (Blattman \& Miguel, 2010; Fearon \& Laitin, 2003). Finally, in several specifications, we include random effects for region and time to account for cross-regional and temporal heterogeneity that is not explicitly modeled. ${ }^{14}$

Before estimating our full model, we explore the straightforward bivariate evidence, with autonomy status lagged 5 years. Figure 1 shows the proportion of cases that engaged in separatism, sorted by autonomy status. It indicates that, not controlling for other facts, groups which lost autonomy were $75 \%$ more likely to lead to separatism than groups that had autonomous status. Moreover, autonomous groups were almost twice as likely to lead to separatism than groups with no history of autonomy.

Figure 1 does not account for the possible correlation across group-years, however. To account for these correlations and to investigate these hypotheses further, we estimate a mixed-effects logistic regression model using the group-level data. Our basic model in scalar form is 


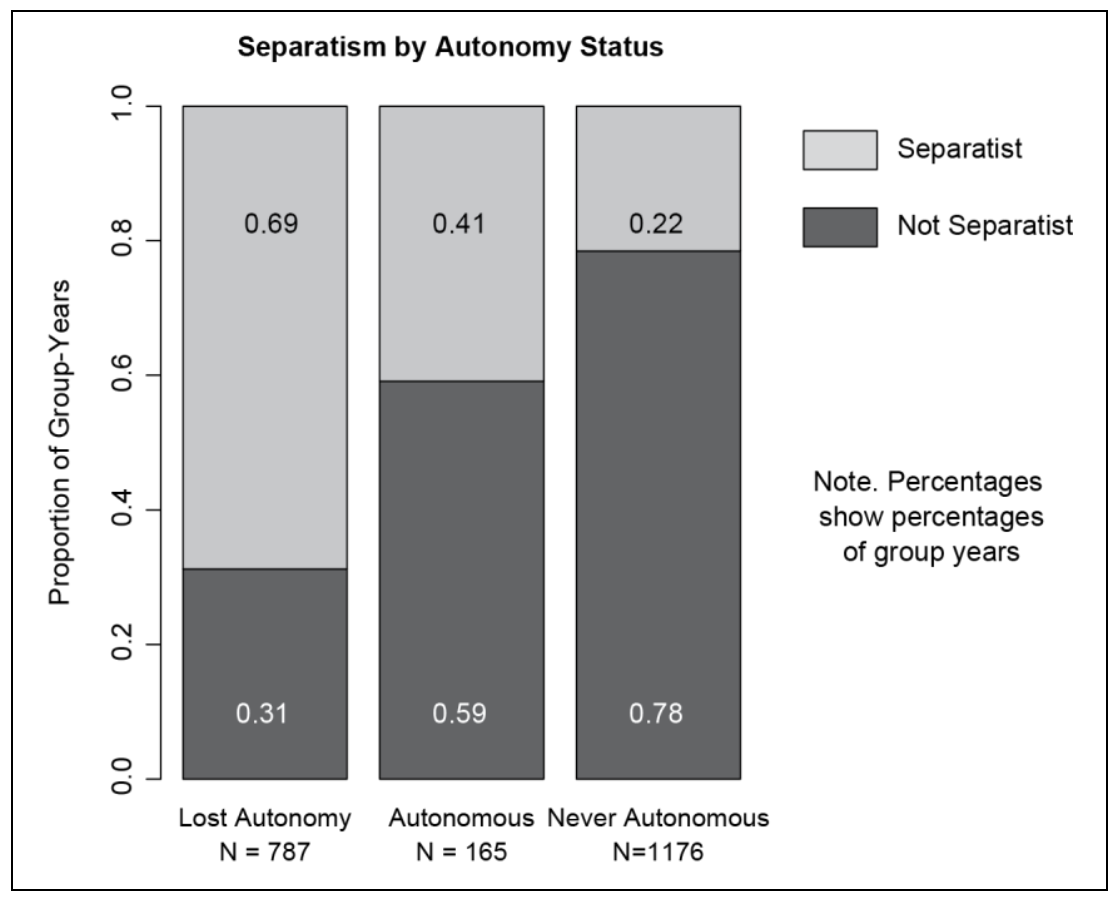

Figure 1. Bar plot of separatism by autonomy status.

$$
\begin{aligned}
p{\text { (Separatism })_{i k t}=} & \beta_{0}+\beta_{1} \text { Autonomy status }_{i k t}+\beta_{2} \text { Regime Type }_{k t}+\beta_{3} \text { Autonomy status }_{i k t} \\
& +\beta_{4} \text { Region }_{k}+\beta_{5}{\text { Excluded Group } 5_{k t}} \\
& +\beta_{6} \text { Logged GDPPC }_{k t}+\beta_{7} \text { Oil }_{i k t}+\beta_{8} \text { External Support }_{i k t}+\varepsilon_{i k t},
\end{aligned}
$$

where $i$ is the subscript for a given group in a country $k$ in time period $t$. Such a model allows us to control for correlation of observations both within each country and across time. In the next section, we discuss the results of our analysis of this model.

\section{Discussion of Results}

The core result shows that the loss of autonomy significantly increases the likelihood of separatism. Table 2 depicts this result using a nonlinear mixed model (Pinheiro, Bates, DebRoy, Sarkar, \& R Development Core Team, 2012). In all specifications, groups that lost autonomy were significantly more likely to be separatist than autonomous groups, and in most models groups which were never autonomous were less likely to become separatist 

Table 2. Nonlinear Mixed-Effects Models.

\begin{tabular}{|c|c|c|c|c|}
\hline & Dichotomous & Cold War & Year & Full \\
\hline & Classification & Random effect & Random effect & Model \\
\hline Intercept & $-2.37(1.27)$ & $-2.52(1.45)$ & $-3.09(1.31)^{*}$ & $-2.58(1.46)$ \\
\hline Lost autonomy & - & $1.85(0.55)^{\star}$ & $2.22(0.58)^{\star}$ & $1.90(0.55)^{*}$ \\
\hline Nonautonomous & $0.18(0.48)$ & $-1.33(0.55)^{\star}$ & $-0.97(0.58)$ & $-1.30(0.55)^{\star}$ \\
\hline Hybrid regime & $0.04(0.42)$ & $0.26(0.47)$ & $0.27(0.46)$ & $0.21(0.47)$ \\
\hline Democracy & $0.09(0.31)$ & $0.36(0.36)$ & $0.36(0.36)$ & $0.30(0.36)$ \\
\hline Group concentration & $1.15(0.12)^{*}$ & $0.96(0.13)^{*}$ & $0.94(0.13)^{*}$ & $0.96(0.13)^{*}$ \\
\hline Excluded groups & $0.00(0.02)$ & $-0.01(0.02)$ & $-0.01(0.02)$ & $-0.01(0.02)$ \\
\hline Logged GDP per capita & $-0.09(0.19)$ & $0.02(0.22$ & $0.08(0.15)$ & $0.06(0.22)$ \\
\hline Oil & $0.26(0.26)$ & $0.22(0.31$ & $0.28(0.31)$ & $0.22(0.31)$ \\
\hline External support & $2.72(0.72)^{\star}$ & $3.15(0.81)^{*}$ & $3.18(0.82)^{*}$ & $3.13(0.82)^{*}$ \\
\hline Eastern Europe and (former USSR) & $-0.96(0.97)$ & $-1.71(1.05)$ & $-1.78(1.05)$ & $-1.71(1.08)$ \\
\hline Latin America & $-5.60(1.28)^{*}$ & $-5.10(1.53)^{*}$ & $-5.22(1.51)^{\star}$ & $-5.19(1.53)^{*}$ \\
\hline North Africa and Middle East & $-0.68(1.13)$ & $-0.68(1.27)$ & $-0.83(1.26)$ & $-0.71(1.27)$ \\
\hline Sub-Saharan Africa & $-2.03(0.86)^{\star}$ & $-2.16(0.96)^{*}$ & $-2.20(0.96)^{*}$ & $-2.18(0.96)^{*}$ \\
\hline Western democracies & $0.09(1.25)$ & $-0.12(1.41)$ & $-0.44(1.31)$ & $-0.17(1.42)$ \\
\hline Year (fixed) & $0.01(0.01)$ & $0(0.02)$ & - & $0.00(0.02)$ \\
\hline Random effects & $5.28(2.3)^{*}$ & $5.41(2.33)^{*}$ & $7.41(2.72)^{*}$ & $6.36(2.52)^{*}$ \\
\hline Country & - & - & $0.00(0.01)$ & - \\
\hline Year & - & - & $0.07(0.27)$ & - \\
\hline Cold War & -486.82 & -408.80 & -406.90 & -409.07 \\
\hline Log likelihood & $1,005.65$ & 855.60 & 849.81 & 852.14 \\
\hline AIC & $1,087.06$ & 952.28 & 941.40 & 938.65 \\
\hline $\mathrm{BIC}$ & $1,198.00$ & $1,198.00$ & $1,198.00$ & $1,198.00$ \\
\hline Countries & 100 & 100 & 100 & 100 \\
\hline Groups & 324 & 324 & 324 & 324 \\
\hline Group-years & 1,198 & 1,198 & 1,198 & 1,198 \\
\hline
\end{tabular}

Standard errors are in parentheses. AIC = Akaike information criterion; BIC = Bayesian information criterion. ${ }^{*} p<.05$. 



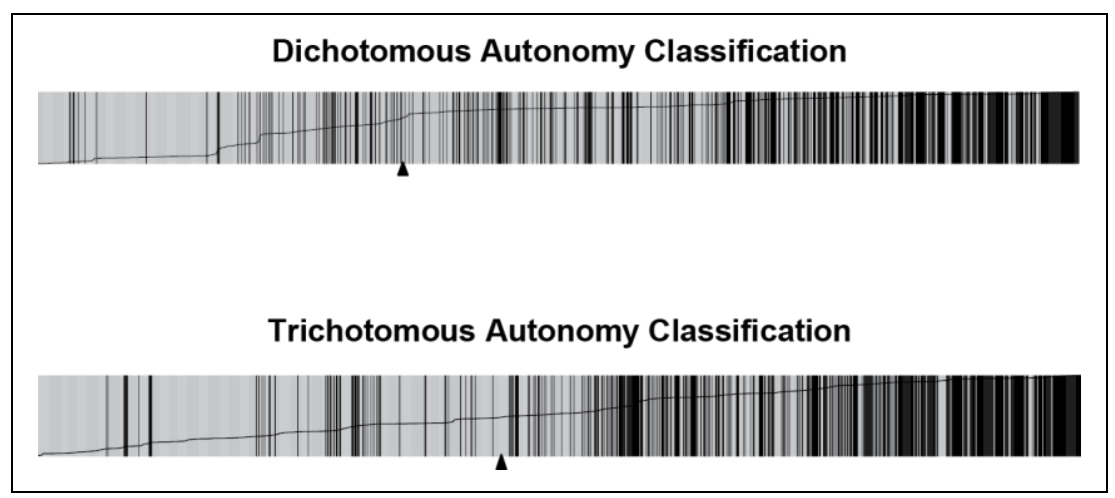

Figure 2. Separation plots of dichotomous and trichotomous model specifications.

than currently autonomous groups. ${ }^{15}$ The results also show that highly spatially concentration groups are more likely to become separatist, and external support for an ethnic group appears to have consistently increased the likelihood a group becomes separatist. However, other factors thought to influence civil war, such as GDP per capita, the number of excluded groups and Oil, do not appear to be associated with more separatism.

We also ran models with a random effect for groups within each state to control for the possibility that groups which launched multiple or constant separatist campaigns during this time period were not unduly biasing our data. While some interpretations change, lost autonomy is almost always significant at the .05 level, and never less than the .10 level. For example, a replication of our full model displayed in Table A2 yields identical results in terms of significance for the main variables of interest, available in the online appendix.

In addition to examining how our covariates relate to the propensity of a group to engage in separatism, we are also interested in the predictive performance of our model specification relative to reasonable alternatives. ${ }^{16}$ At the level of predictive accuracy, all models using the trichotomous autonomy indicator out-performed the model using a dichotomous classification by a substantively significant margin (Figures 2 and 3). Figure 2 shows a separation plot (Greenhill, Ward, \& Sacks, 2011), which graphically illustrates the classification accuracy using gray bars to indicate incorrect predictions of separatism, and black bars to predict correct ones. The thin black line indicates the predicted probability of each observation. A 
model with perfect classification accuracy would show all black bars to the

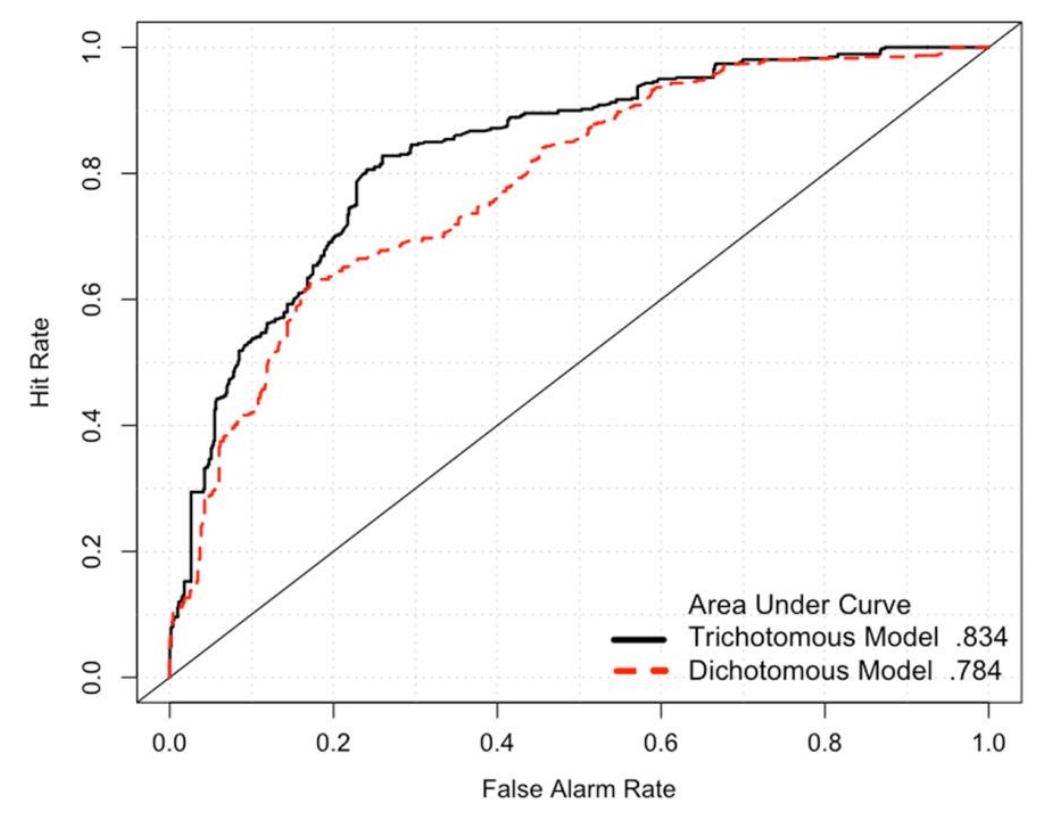

Figure 3. ROC plot of dichotomous and trichotomous model specifications.

right and gray ones to the left, whereas a model no better than a coin flip would show equal numbers of black and gray bars on the right and the left side of the spectrum.

Figure 3 shows a traditional ROC (Receiver or Relative Operating Characteristic) plot (NCAR: Research Application Program, 2012), which also illustrates the predictive accuracy. When the curve is closer to the northwest corner of the plot, the model provides more predictive accuracy. It reinforces the fact that models using the trichotomous indicator of autonomy out-perform models using a dichotomous indicator of autonomy.

The proposed model demonstrates some of the important conceptual and empirical advantages to disaggregation, and out-perform models using a dichotomous indicator of autonomy in terms of precision. Figure 4 shows a coefficient plot for the full model, which underscores the clear positive effect of lost autonomy on the likelihood of secession. ${ }^{17}$ 


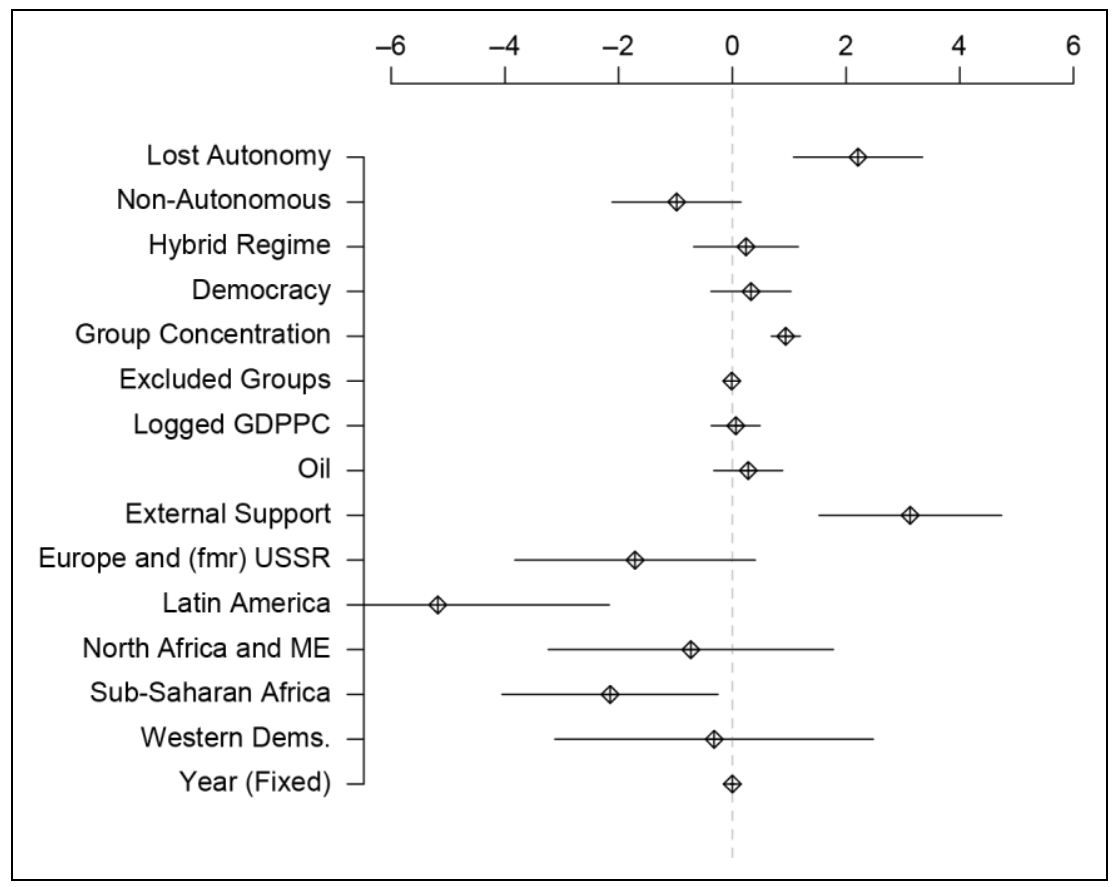

Figure 4. Coefficient plot for the full model specification in Table 2.

\section{Robustness}

As groups are not randomly assigned to their respective autonomy categories, and researchers are unable to manipulate the assignment to groups, care must be taken in making causal statements.

Autonomy is retracted and lost through disparate causal processes, which fall outside the scope of our argument concerning its effect. Access to resources may encourage a state to expand into its periphery, and thus to encroach on an ethnic group's traditional territory. Or the motives may be less economic and more political: A borderland inhabited by "ethnic others" is deprived of its autonomous status for fear that it may become a fifth column in an interstate dispute. This analysis is agnostic on which of these reasons best accounts for a region's loss of autonomy, yet we would agree that further disaggregation along these lines could result in the discovery of important theoretical distinctions between economically motivated versus politically driven autonomy retraction and status reversal.

Our primary concern is to address the possibility that the model is endogenous - separatist activity leads to the retraction of autonomy. Although we are careful to ensure that we code autonomy prior to separatism, it is impossible to know with certainty in every case that the group did not 
display signs of separatism prior to being annexed or having its status demoted. In addition to examining the timing of all cases that were coded as having lost autonomy, we also pursued more formal techniques to ensure the robustness of the results, including pre-processing the data using genetic matching, instrumental variables regression and a Bayesian approach to generalized mixed models.

Genetic Matching is a method that seeks to make results less dependent upon modeling assumptions. By balancing data using "treatment" and "control" groups, the goal is to break any potential link between the treatment variable and the other covariates by ensuring that both treatment and control groups have similar distributions of covariates other than the key treatment (A. Diamond \& Sekhon, 2006; Sekhon, 2004). As our "treatment" is trichotomous, we follow the recommendation of Ho, Imai, King, and Stuart (2007) and dichotomize our variable to ensure that all comparisons are made. ${ }^{18}$ After generating matched data based on three combinations of autonomy status, we estimated Bayesian nonlinear mixed-effects models (Hadfield, 2010), shown in Table 3.

Although we are unable to conduct comparisons with our full model due to insufficient matches when including external support, we show that the posited relationship between autonomy status and separatism holds when using matched data on a reduced model without external support: Autonomy loss significantly increases the likelihood of a group becoming separatist compared with both autonomous and never autonomous groups, and currently autonomous groups are generally more likely to become separatist than groups who were never autonomous. Although the robustness of these results to matching on covariates provides additional empirical support for our primary hypotheses, we recognize that it does not rule out other threats to valid inference. As matching only pushes the dependence back to the choice of criteria (variables, model) for defining the matches, there is still the possibility of omitted variables that could drive the matches, which in turn could influence the reported results.

Next, we examine whether the results are robust to modifying the coding of the dependent variable from a dichotomous indicator of separatism to an ordered measure of the separatism. Using data from the Peace Research Institute Oslo's conflict intensity data (N. P. Gleditsch, Wallensteen, Eriksson, Sollenberg, \& Strand, 2002), combined with our indicator of separatism, we code for four levels of separatism: nonseparatist, separatist 

Table 3. Models Using Matched Data.

\begin{tabular}{|c|c|c|c|}
\hline & $\begin{array}{c}\text { Baseline: } \\
\text { Never Autonomous }\end{array}$ & $\begin{array}{c}\text { Baseline: } \\
\text { Never Autonomous }\end{array}$ & $\begin{array}{c}\text { Baseline: } \\
\text { Autonomous }\end{array}$ \\
\hline Intercept & $0.70(4.76)$ & $-3.24(1.91)^{*}$ & $1.80(2.87)$ \\
\hline $\begin{array}{l}\text { Lost } \\
\text { Autonomy }\end{array}$ & - & $3.87(0.41)$ * & $1.81(0.44)$ * \\
\hline Autonomous & $1.06(0.56)$ & - & - \\
\hline Democracy & $0.82(1.47)$ & $-0.17(0.68)$ & $-0.19(0.96)$ \\
\hline $\begin{array}{l}\text { Partial } \\
\text { Democracy }\end{array}$ & $1.50(1.21)$ & $-0.36(0.49)$ & $0.14(0.61)$ \\
\hline $\begin{array}{l}\text { Group } \\
\text { Concentration }\end{array}$ & $-1.02(99)$ & $1.15(0.22)^{*}$ & $0.20(0.25)$ \\
\hline $\begin{array}{l}\text { E. Europe } \\
\text { and (fmr) } \\
\text { USSR }\end{array}$ & $1.93(3.07)$ & $-3.54(1.51)^{*}$ & $-7.64(2.31)^{*}$ \\
\hline $\begin{array}{l}\text { Latin } \\
\text { America }\end{array}$ & $-2.68(2.22)$ & $-2.97(1.97)$ & $-6.08(3.40)^{*}$ \\
\hline $\begin{array}{l}\text { North Africa } \\
\text { and ME }\end{array}$ & $3.25(1.95)$ & $0.26(1.95)$ & $-0.32(3.00)$ \\
\hline $\begin{array}{l}\text { Sub-Saharan } \\
\text { Africa }\end{array}$ & $-1.86(1.41)$ & $-2.93(1.38)^{*}$ & $-3.61(2.16){ }^{*}$ \\
\hline $\begin{array}{l}\text { Western } \\
\text { Democracies }\end{array}$ & $4.25(3.23)$ & $0.63(2.10)$ & $1.85(4.02)$ \\
\hline $\begin{array}{l}\text { Excluded } \\
\text { Groups }\end{array}$ & $-0.05(0.07)$ & $-0.02(0.02)$ & $0.01(0.02)$ \\
\hline $\begin{array}{l}\text { Logged } \\
\text { GDPPC }\end{array}$ & $-0.10(0.74)$ & $-0.14(0.30)$ & $0.12(0.42)$ \\
\hline Oil & $0.77(0.52)$ & $0.11(0.41)$ & $0.53(0.37)$ \\
\hline Year (Fixed) & $-0.01(0.05)$ & $0.02(0.02)$ & $-0.00(0.03)$ \\
\hline \multicolumn{4}{|l|}{$\begin{array}{l}\text { Random } \\
\text { Effects }\end{array}$} \\
\hline Country & $1.58(1.26)^{*}$ & $12.17(3.48)^{*}$ & $20.75(4.55)^{*}$ \\
\hline $\begin{array}{l}\text { Log- } \\
\text { Likelihood }\end{array}$ & -23.39 & -264.74 & -214.61 \\
\hline Deviance & 46.77 & 529.49 & 459.23 \\
\hline AIC & 214.01 & 559.49 & 523.96 \\
\hline BIC & 264.57 & 628.34 & 452.83 \\
\hline $\mathrm{N}$ & 77 & 730 & 475 \\
\hline Groups & 21 & 86 & 66 \\
\hline
\end{tabular}


Table 4. Posterior Means for Bayesian Hierarchical Ordered Logistic Models.

\begin{tabular}{|c|c|c|}
\hline & $\begin{array}{c}\text { Mean } \\
\text { (Std. Dev) }\end{array}$ & $\begin{array}{l}\text { Credible } \\
\text { Intervals }\end{array}$ \\
\hline Autonomous & $0.41(0.47)$ & {$[-0.52,1.34]$} \\
\hline Lost Autonomy & $1.91(0.17)^{*}$ & {$[1.59,2.25]$} \\
\hline Partial Democracy & $-0.07(0.24)$ & {$[-0.54,0.40]$} \\
\hline Democracy & $-0.15(0.29)$ & {$[-0.73,0.42]$} \\
\hline Group Concentration & $0.53(0.09){ }^{*}$ & {$[0.37,0.70]$} \\
\hline External Support & $1.02(0.24){ }^{*}$ & {$[0.55,1.50]$} \\
\hline Excluded Groups & $0.01(0.02)$ & {$[-0.02,0.44]$} \\
\hline GDPPC (Logged) & $-0.11(0.15){ }^{*}$ & {$[-0.42,-0.19]$} \\
\hline E. Europe/former USSR & $-0.43(0.71)$ & {$[-1.71,1.00]$} \\
\hline Latin America & $-2.51(0.42)$ & {$[-2.99,-1.57]$} \\
\hline Middle East and North Africa & $0.00(.82)$ & {$[-1.62,1.57]$} \\
\hline Sub-Saharan Africa & $-1.05(0.64)$ & {$[-2.13,0.29]$} \\
\hline Western Democracies & $0.20(0.95)$ & {$[-1.52,0.20]$} \\
\hline Year & $0.01(0.31)$ & {$[-0.02,0.04]$} \\
\hline Post-Cold War & $0.16(0.01)$ & {$[-0.45,0.76]$} \\
\hline Cut-points & - & - \\
\hline No Separatism: Peaceful Separatism & $-1.98(0.02){ }^{*}$ & {$[-1.99,-1.93]$} \\
\hline Peaceful Separatism: Minor Conflict & $0.35(0.08)^{*}$ & {$[0.16,0.52]$} \\
\hline Minor Conflict: Major Conflict & $1.98(0.02)^{*}$ & {$[1.93,2.00]$} \\
\hline Countries & 100 & \\
\hline Groups & 324 & \\
\hline Group-Years & 1198 & \\
\hline
\end{tabular}

Standard deviations are in parentheses, $95 \%$ credible intervals in brackets. Minor conflict if less than 20 battle deaths per year, and major conflict if more than 20 battle deaths per year. $*$ Indicates the probability of the coefficient being <.05.

but peaceful, minor separatist conflict ( $<25$ battle deaths per year), and major separatist conflict ( $>25$ battle deaths per year). The ordered model shows that groups that have lost autonomy are likely to engage in more intense separatism than both currently autonomous and never autonomous groups. ${ }^{19}$

These results are displayed in Table $4 .{ }^{20}$ Figures 5 and 6 illustrate the the posterior densities and trace plots for groups that lost their autonomy and then for groups which were never autonomous. ${ }^{21}$

\section{Conclusion}

In his Second Treatise, John Locke observed that men are unlikely to cause revolutions for trivial reasons. This analysis shows that a tangible loss of autonomy is a nontrivial issue, and is robustly associated with separatism. 


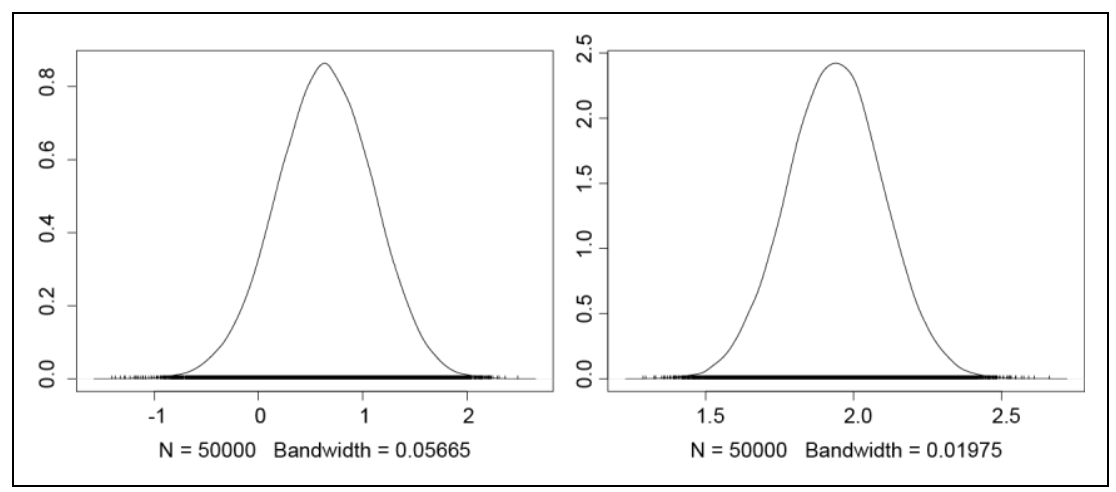

Figure 5. Posterior density plot for autonomous $(\mathrm{L})$ and lost autonomy $(\mathrm{R})$.

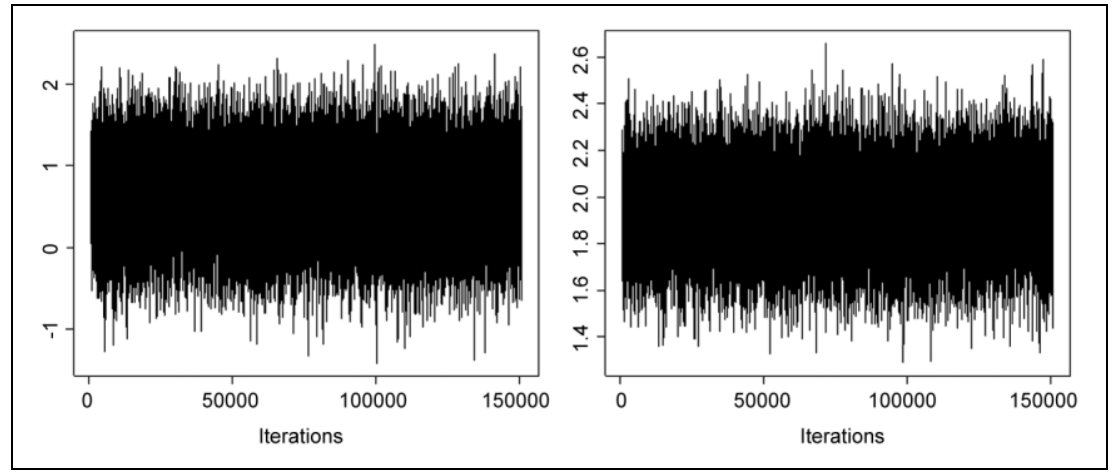

Figure 6. Trace plot for autonomous $(\mathrm{L})$ and lost autonomy $(\mathrm{R})$.

The retraction of autonomy provides a strong motive by invariably increasing grievances against the central state while not necessarily decreasing the group's collective action capacity. By disaggregating the omitted category in research on the institutional determinants of conflict, and showing that lost autonomy represents a conceptually distinct class of group status, our findings go some way toward explaining the "empirical murkiness" within the academic literature on the relationship between institutional arrangements, such as ethno-federalism, and separatism.

Taking concept formation seriously can yield new insights and can highlight important theoretical and empirical distinctions. By separating groups that have lost autonomy from groups who have never been autonomous - which were previously lumped together as "non-autonomous" in many analyses - this article contributes to the literature on decentralization and on secessionist collective action. Whether autonomy whets the appetite 
of ethnic groups to seek independence, or saps their desire by providing indirect rule, and some degree of control over their own affairs and fate, depends on the group's beliefs about the credibility of the government's commitment to guaranteeing its status. The results suggest that autonomous groups are not significantly more likely than groups that have never been autonomous to become separatists, but groups that lost autonomy are twice as likely to pursue secession, compared with currently autonomous and never autonomous groups.

We are not unaware that this finding may have some implications for the rational design of institutional arrangements for peripheral regions. Containing nationalism is certainly possible. However, any state that is motivated to revoke autonomy on the basis of anticipated economic or political benefits for the state must weigh these potential benefits against the increase in the probability that the group will pursue separatism. Future research should unpack the circumstances under which different states are going to find the costs to outweigh the benefits. From Asia to Europe and Africa, states that have elected to retract autonomy as a means to rally political support for elections, to secure economic benefits from lootable resources or transit fees, or to remove a potential fifth column, have found that the costs often exceed the benefits, for groups frequently reply to a diminution of their status by mobilizing for separatism. The Albanian Kosovars in Serbia, the Abkhaz in Georgia, the Tibetans and Uighurs in China, or the South Sudanese and Biafrans in Africa all illustrate this stategroup dynamic.

While these qualifications highlight the need for further research into the causal mechanisms responsible for the mobilization of ethnic groups and the intensity of separatist campaigns, we believe this article represents a significant contribution to our understanding of autonomy and separatism. Using newly disaggregated empirical evidence on the loss of autonomous status and data on separatism, the analysis indicates that retracted autonomy increases grievances against the central state while often failing to reduce the group's collective action capacity. These results address an important debate with a new conceptual angle and new data, while suggesting new directions for future research.

\section{Acknowledgments}

This article and early musings on the subject benefited from helpful comments and encouragement that we would like to recognize: Roy Allison, David Aprasidze, Yael Aronoff, Mark Axelrod, Galia Benitez, Lenka Bustikova, Dennis Dafflon, Alexis Diamond, Alexander Downes, Ross Emmett, Sherman Garnett, Norm Graham, Bernard Grofman, Giorgi Gvalia, Henry Hale, Michael Hechter, Courtney Hillebrecht, Donald Horowitz, Erin Jenne, Elene Jibladze, Alice Kang, Nam Kyu Kim, Matthew Kocher, Ari Kohen, Hrant Kostanyan, Adria Lawrence, Levente Littvay, Jason Lyall, Anthony McGann, Patrice McMahon, Ross Miller, Emily Molfino, Harris Mylonas, 
Nino Pavlenishvili, Natalia Peral, Linda Racioppi, Wolfgang Reinicke, Nicholas Sambanis, Tariel Sikharulidze, Erik Wibbels, and Matt Zierler. We are also grateful for anonymous feedback from the review process, and for suggestions from audience members at Arizona State University, Academic Swiss Caucasus Net, Association for the Study of Nationalities, Central European University, Michigan State University, University of California-Irvine, and University of Nebraska-Lincoln.

\section{Notes}

1. For a case to satisfy the definition of autonomy adopted here, this arrangement must be institutionalized, yet we recognize that the extent of institutionalization varies by country and context. For example, in relatively strong states, such as Spain, the formal limits of autonomy (e.g., for Catalonia) may be very well specified, whereas in weaker states, autonomy may be less formalized, but nonetheless widely recognized and acknowledged (e.g., Westerners in Cameroon prior to 1975).

2. Artur Mas I Gavarro of the CDC.

3. We are cognizant that the meaning of autonomy is contextual, and may vary not only from place to place but also over time. This is especially an issue for autonomies in autocracies, where the degree of self-rule is often pro forma. In China, for instance, formal autonomy is mainly a fiction-formally autonomous Xinjiang and Tibet are arguably less autonomous than Shanghai or Guangdong, which are not formally autonomous. In our coding of such cases, we are careful to account for this contextual difference across countries. We also conduct the analysis controlling for regime type, and with separate samples for each regime type, to examine whether the main results are robust.

4. We are cognizant that separatism is often ill-defined. Some (Treisman, 1997) argue separatism is a "spectrum" from demands to increased local powers through full separation from the state (p. 214). Here, we follow Cederman, Wimmer, and Min (2010) in defining separatism as the pursuit of independence from the central government — not necessarily the achievement of independence.

5. Although we focus on the pursuit of secession, rather than on rebellion in this article, this disaggregated approach may also shed light on the findings in Gurr (1993) and Gurr and Moore (1997); in the former, lost autonomy was a significant predictor of rebellion, but it was not in the latter.

6. These events have led some scholars to describe the ensuing conflict as one based on contestation of resources, rather than ethnic differences (Suliman, 1997). Our position is that seizing oil fields, and instituting Islamic policies, were both part of the process of reducing the South's autonomy, and is therefore consistent with our argument.

7. While not directly related to separatism, see Posner's (2004) discussion of how the ethnic makeup within different states alters the salience of ethnic cleavages.

8. http://www.epr.ucla.edu/

9. www.cidem.umd.edu/mar 
10. The original coding is unordered with four levels: No Separatism, Latent Separatism, Historical (1940-1980) Separatism, and Active (1980-2000) Separatism. As our main interest here is on the presence of separatism, we coded a group-year as "1" if it met either the condition of Historical or Active Separatism for that year. We then checked these findings against Ethnic Power Relations' (EPR) Secessionist Autonomy indicator as well as the Minorities at Risk (MAR) Qualitative data to ensure there was an active separatist movement for the group in the given period. The results from an ordered model produce similar results (Table 4) and thus we focus on discussing the more straightforward findings using a dichotomous dependent variable in our main analyses (Table 2).

11. The AUTLOST index is calculated by adding the values of the group's prior status and the magnitude of autonomy change, subtracting 1 , and then dividing by a factor indicating the decade of autonomy retraction. We also cross-examined the results with MAR qualitative data and EPR's “auton” variable.

12. This variable measures percentage of an ethnic group living within a particular region of the state. Groups not in the MAR data were assigned according to these criteria.

13. For example, to measure support in 1980, we took values from 1975 to 1980 and took the mean.

14. We estimated a Bayesian Hierarchical Logistic regression model using the JAGS statistical software. See Table 4 in the main text.

15. See Table A1 in the online appendix for a pooled analysis of the data that treats the pre- and post-Cold War periods as distinct.

16. Or compared with a monkey throwing darts, to use a recently publicized example. See "Political Scientists Are Terrible Predictors," The New York Times, June 24, 2012.

17. In the plot, the horizontal lines represent \pm 2 standard errors, while the points represent the estimated coefficient.

18. Matching therefore encompasses comparisons between groups who were never autonomous and groups who lost their autonomy, and groups who were never autonomous and groups who are currently autonomous.

19. It also shows that there is no statistically significant difference between autonomous groups and groups which have never had autonomy in terms of the likelihood to engage in intense separatism.

20. We adopt a Bayesian approach for this model and allowed the model 500,000 iterations, with a burn-in of 200,000 iterations.

21. As an additional check, reported in the supplementary online appendix, we divide the autonomy lost indicator further into autonomy lost more or less than 50 years prior to the year $t$. If a group lost autonomy in 1930, it was classified as having autonomy lost within 50 years until 1980, and then as having lost autonomy more than 50 years ago. It shows that both more recent and more distant losses of autonomy lead to separatism more often than among autonomous groups and never autonomous groups (the baseline category).

\section{References}

Adar, K. G. (1998). A state under siege: The internationalization of the Sudanese Civil War. African Security Review, 7(1), 44-53. 
Agence France Presse. (1995, February 17). Unknown Albanian "liberation army" claims Kosovo attacks. http://lexis-nexis.com/universe.

Ahmed, F. (2012). The perils of unearned foreign income: Aid, remittances, and government. American Political Science Review, 106, 146-155.

Baruah, S. (2009). Separatist militants and contentious politics in Assam, India: The limits of counterinsurgency. Asian Survey, 49, 951-974.

Bennett, J. (1987). The hunger machine. Cambridge, UK: Polity Press.

Bermeo, N. (2002). The import of institutions. Journal of Democracy, 13, 96-110.

Bermeo, N., \& Amoretti, U. (2003). Federalism and territorial cleavages. Baltimore, MD: Johns Hopkins University Press.

Beshir, M., Mohammad-Salih, M. A., \& Abdul-Jalil, M. A. (1984). The Sudan: Ethnicity and national cohesion (Bayreuth African Studies Series). Bayreuth, Germany: Universitat Bayreuth.

Biel, M. R. (2003). The Civil War in Southern Sudan and its effect on youth and children. Social Work and Society International Online Journal, 1, 119-127.

Blattman, C., \& Miguel, E. (2010). Civil war. Journal of Economic Literature, 48, 357.

Bound, J., Jaeger, D. A., \& Baker, R. M. (1995). Problems with instrumental variables estimation when the correlation between the instruments and the endogenous explanatory variable is weak. Journal of the American Statistical Association, 90, 443-450.

Brancati, D. (2009). Peace by design. New York, NY: Oxford University Press.

Brass, P. R. (1991). Ethnicity and nationalism: Theory and comparison. Newbury Park, CA: SAGE.

Bunce, V. (1999). Subversive institutions: The design and the collapse of socialism and the state. New York, NY: Cambridge University Press.

Bustikova, L. (2014, in press). Revenge of the radical right. Comparative Political Studies 48 (12): 1738-1765.

Cederman, L.-E., Wimmer, A., \& Min, B. (2010). Why do ethnic groups rebel? New data and analysis. World Politics, 62, 87-119.

Clark, H. (2000). Civil resistance in Kosovo. London, England: Pluto Press.

Collier, P., \& Hoeffler, A. (2004). Greed and grievance in civil war. Oxford Economic Papers, 56, 563-595.

Coppieters, B. (2001). Federalism and conflict in the Caucasus. London, England: Royal Institute of International Affairs.

Cornell, S. E. (2002). Autonomy as a source of conflict: Caucasian conflicts in theoretical perspective. World Politics, 54, 245-276.

Costalli, S., \& Moro, F. N. (2012). Ethnicity and strategy in the Bosnian civil war: Explanations for the severity of violence in Bosnian municipalities. Journal of Peace Research, 49, 801-815.

Cunningham, K., \& Beaulieu, E. (2010). Dissent, repressions, and inconsistency. In E. Chenoweth \& A. Lawrence (Eds.), Rethinking violence (pp. 173-196). Cambridge, MA: MIT Press. 
Darnell, A. T., \& Parikh, S. (1988). Religion, ethnicity, and the role of the state: Explaining conflict in Assam. Ethnic and Racial Studies, 11, 263-281.

Dasgupta, K., \& Guha, A. (1985). 1983 assembly poll in Assam: An analysis of its background and implications. Economic and Political Weekly, 20, 843-853.

Deng, F. M. (2006). Sudan: A nation in turbulent search of itself. Annals of the American Academy of Political and Social Science, 603, 155-162.

Diamond, A., \& Sekhon, J. S. (2006). Genetic matching for estimating causal effects: A general multivariate matching method for achieving balance in observational studies. Review of Economics and Statistics, 95, 932-945.

Diamond, L. (1999). Developing democracy: Toward consolidation. Baltimore, MD: Johns Hopkins University Press.

Eprile, C. (1974). War and peace in the Sudan, 1955-1972. London, England: David \& Charles.

Epstein, D., Bates, R., Goldstone, J., Kristensen, I., \& O’Halloran, S. (2006). Democratic transitions. American Journal of Political Science, 50, 551-556.

Fearon, J. D., \& Laitin, D. D. (2003). Ethnicity, insurgency, and Civil War. American Political Science Review, 97, 75-90.

Forrest, J. B. (2004). Subnationalism in Africa: Ethnicity, alliances, and politics. Boulder, CO: Lynne Rienner Publishers.

Fuller, G., Morrison, R., Murphy, A., \& Ridley, M. (2002). Potential for ethnic conflict in China. Eurasian Geography and Economics, 43, 583-611.

Ghai, Y. (2000). Autonomy and ethnicity: Negotiating competing claims in multiethnic states. Cambridge, UK: University Press Cambridge.

Gladney, D. C. (2003). Islam in China: Accommodation or separatism? The China Quarterly, 174, 451-467.

Gleditsch, K. S. (2008). Modified polity P4 and P4D data (3rd ed.). Retrieved from http://www.systemicpeace.org/polity/polity4.htm

Gleditsch, N. P., Wallensteen, P., Eriksson, M., Sollenberg, M., \& Strand, H. (2002). Armed conflict 1946-2001: A new dataset. Journal of Peace Research, 39, 615637.

Greenhill, B., Ward, M., \& Sacks, A. (2011). The separation plot: A new visual method for evaluating the fit of binary models. American Journal of Political Science, 55, 991-1002.

Gurr, T. R. (1993). Why minorities rebel: A global analysis of communal mobilization and conflict since 1945. International Political Science Review, 14, 161-201.

Gurr, T. R. (2000). Peoples versus states: Minorities at risk in the new century. Washington, DC: United States Institute of Peace.

Gurr, T.R., \& Moore, W. (1997). Ethnopolitical rebellion: A cross-sectional analysis of the 1980s with risk assessments for the 1990s. American Journal of Political Science, 41, 1079-1103.

Gurr, T. R. (2009). Minorities at risk dataset. Retrieved from http://www.cidcm.umd.edu/mar/

Guss, J., \& Siroky, D. (2012). Living with heterogeneity: Bridging the ethnic divide in Bosnia and beyond. Comparative Sociology, 11, Article 304.

Hadfield, J. (2010). Mcmc methods for multi-response generalised linear mixed models: The mcmc-glmm r package. Journal of Statistical Software, 33(2), 1-22.

Hale, H. E. (2000). The parade of sovereignties: Testing theories of secession in the soviet setting. British Journal of Political Science, 30, 31-56. 
Hale, H. E. (2008a). The double-edged sword of ethnofederalism: Ukraine and the USSR in comparative perspective. Comparative Politics, 40, 293-312.

Hale, H. E. (2008b). Foundations of ethnic politics: Separatism of states and nations in Eurasia and the world. Cambridge, UK: Cambridge University Press.

He, B., \& Sautman, B. (2005). The politics of the Dalai Lama's new initiative for autonomy. Pacific Affairs, 78, 601-629.

Hechter, M. (1975). Internal colonialism: The Celtic fringe in British national development, 1536-1966. Berkeley: University of California Press.

Hechter, M. (2000). Containing nationalism. New York, NY: Oxford University Press.

Hechter, M. (2013). Alien Rule. New York, NY: Cambridge University Press.

Hechter, M., \& Okamoto, D. (2001). Political consequences of minority group formation. Annual Review of Political Science, 4, 189-215.

Hirschman, A. (1970). Exit, voice, and loyalty. Cambridge, MA: Harvard University Press.

Ho, D. E., Imai, K., King, G., \& Stuart, E. A. (2007). Matching as nonparametric preprocessing for reducing model dependence in parametric causal inference. Political Analysis, 15, 199-236.

Horowitz, D. (1985). Ethnic groups in conflict. Berkeley: University of California Press.

Jenne, E. (2007). Ethnic bargaining. Cornell, NY: Cornell University Press.

Jenne, E. (2010). Managing European conflicts through devolution: Lessons from the league of nations (EUI Working Paper RSCAS, 65). Retrieved from http://cadmus.eui.eu/handle/1814/14615

Judah, T. (2002). Kosovo: War and revenge. New Haven, CN: Yale University Press.

Kalita, R. (2009). Writing terror: Men of rebellion and contemporary Assamese literature. In S. Baruah (Ed.), Beyond counterinsurgency: Breaking the impasse in Northeast India (pp. 101-123). New Delhi, India: Oxford University Press.

Kalyvas, S. N., \& Kocher, M. A. (2007). How "free" is free riding in civil wars? Violence, insurgency, and the collective action problem. World Politics, 59, 177216.

Karmel, S. M. (1995). Ethnic tension and the struggle for order: China's policies in Tibet. Pacific Affairs, 68, 485-508.

Kaufman, C. (1996). Possible and impossible solutions to ethnic civil wars. International Security, 20(1), 136-175.

Kebbede, G. (1997a). South Sudan: A divided and war-torn region. Contributions in Black Studies, 15, 48-63.

Kebbede, G. (1997b). Sudan: The north-south conflict in historical perspective. Contributions in Black Studies, 15, 15-47.

Kubo, K. (2011). Kosovo: Secession under UN supervision. In A. Pavkovic \& P. Radan (Eds.), The Ashgate research companion to secession (pp. 171-190). New York, NY: Ashgate Publishing Company.

Kymlicka, W. (2008). Finding our way: Rethinking ethnocultural relations in Canada. New York, NY: Oxford University Press. 
Lado, C. (2002). Political economy of the oil industry in the Sudan problem or resource in development. Erdkunde, 56, 157-169.

Lijphart, A. (1977). Democracy in plural societies: A comparative exploration. New Haven, CN: Yale University Press.

Lujala, P., Rod, J. K., \& Thieme, N. (2007). Fighting over oil: Introducing a new dataset. Conflict Management and Peace Science, 24, 239-256.

Malcom, N. (1998). Kosovo: A short history. London, England: Macmillan.

Mampilly, Z. (2011). Rebel rulers. Cornell, NY: Cornell University Press.

McGarry, J., \& O'Leary, B. (1993). Introduction: The macro-political regulation of ethnic conflict. In J. McGarry \& B. O'Leary (Eds.), The politics of ethnic conflict regulation: Case studies of protracted ethnic conflicts (pp. 1-40). London, England: Routledge.

McGwire, M. (2000). Why did we bomb Belgrade? International Affairs (Royal Institute of International Affairs 1944-), 76, 1-23.

Miodownik, D., \& Cartrite, B. (2010). Does political decentralization exacerbate or ameliorate ethnopolitical mobilization? A test of contesting propositions. Political Research Quarterly, 63, 731-746.

Misra, U. (1995). Army killings in Assam. Economic and Political Weekly, 30(15), 793.

NCAR: Research Application Program. (2012). Verification: Forecast verification utilities ( $\mathrm{R}$ package version 1.35). Retrieved from http://cran.rproject.org/web/packages/verification/verification.pdf

North, D., \& Weingast, B. (1989). Constitutions and commitment: The evolution of institutions governing public choice in 17th century England. Journal of Economic History, 49, 803-832.

O'Hanlon, M. E., \& Joseph, E. P. (2007, Winter). A Bosnia option for Iraq, United States Department of Least Bad Iraq Options. American Interest. Retrieved from http://www.brookings.edu/research/articles/2007/01/winter-iraq-ohanlon

Petersen, R. D. (2002). Understanding ethnic violence: Fear, hatred, and resentment in twentieth-century Eastern Europe. Cambridge, UK: Cambridge University Press.

Pinheiro, J., Bates, D., DebRoy, S., Sarkar, D., \& R Development Core Team. (2012). nlme: Linear and nonlinear mixed effects models. Retrieved from http://cran.rproject.org/web/packages/nlme/nlme.pdf

Posner, D. N. (2004). The political salience of cultural difference: Why Chewas and Tumbukas are allies in Zambia and adversaries in Malawi. American Political Science Review, 98, 529-545.

Pula, B. (2004). The emergence of the Kosovo "parallel state," 1988-1992. Nationalities Papers, 32, 797-826.

Roeder, P. G. (1991). Soviet federalism and ethnic mobilization. World Politics, 43, 196-232.

Rogowski, R. (1985). Causes and varieties of nationalism: A rationalist account. In E. A. Tiryakian \& R. Rogowski (Eds.), New nationalisms of the developed west (pp. 87-108). New York, NY: Allen and Unwin.

Salehyan, I., Gleditsch, K. S., \& Cunningham, D. E. (2011). Explaining external support for insurgent groups. International Organization, 65, 709-744. 
Salih, M. (1994). The ideology of the Dinka and the Sudan People's Liberation Movement. In K. Fukui \& J. Markakis (Eds.), Ethnicity and conflict in the horn of Africa (pp. 187-201). Oxford, UK: James Currey.

Sambanis, N., \& Zinn, A. (2005). From protest to violence: An analysis of conflict escalation with an application to self-determination movements. Unpublished manuscript.

Sautman, B. (1999). The Tibet issue in post-summit Sino-American relations. Pacific Affairs, 72, 7-21.

Sautman, B. (2005). China's strategic vulnerability to minority separatism. Asian Affairs, 32, 87-118.

Saxton, G. (2005). Repression, grievances, mobilization, and rebellion: A new test of Gurr's model of ethnopolitical rebellion. International Interactions, 31, 1-30.

Sekhon, J. S. (2004). The varying role of voter information across democratic societies. In Annual Meeting of the Midwestern Political Science Association. Retrieved from http://polmeth.wustl.edu/mediaDetail.php?docId=39

Shakya, T. (1999). A dragon in the land of snows. New York, NY: Columbia University Press.

Silber, L., Little, A., \& British Broadcast Corporation. (1996). Yugoslavia: death of a nation. Penguin Books. Retrieved from http://books.google.com/books/about/ Yugoslavia.html?id=QJztAAAAMAAJ

Sinha, S. (2007). Lost opportunities: 50 years of insurgency in the North-east and India's response. New Delhi, India: Lancer Publishers.

Siroky, D., \& Aprasidze, D. (2011). Guns, roses and democratization: Huntington's secret admirer in the Caucasus. Democratization, 18, 1227-1245.

Siroky, D., Dzutsev, V., \& Hechter, M. (2013). The differential demand for indirect rule: Evidence from the North Caucasus. Post-Soviet Affairs, 29, 268-286.

Slezkine, Y. (1994). The USSR as a communal apartment, or how a socialist state promoted ethnic particularism. Slavic Review, 53, 414-452.

Sovey, A. J., \& Green, D. P. (2011). Instrumental variable estimation in political science. American Journal of Political Science, 55, 188-200.

Stepan, A. (1999). Federalism and democracy: Beyond the U.S. model. Journal of Democracy, 10(1), 19-34.

Streat-Bartlett, A. (2009). Secessionist conflict in post-soviet republics. Presented at annual meeting of the Southern Political Science Association, New Orleans, LA.

Suliman, M. (1997). Civil war in Sudan: The impact of ecological degradation. Contributions in Black Studies, 15, 99-121.

Teufel, J. D. (2005). China's vulnerability to minority separatism. Asian Affairs, 32, 69-86.

Toft, M. D. (2003). The geography of ethnic violence: Identity, interests, and the indivisibility of territory. Princeton, NJ: Princeton University Press.

Treisman, D. (1997). Russia's "ethnic revival": The separatist activism of regional leaders in a post-communist order. World Politics, 49, 212-249.

Tsebelis, G. (1990). Elite interaction and constitution building in consociational democracies. Journal of Theoretical Politics, 2, 5-29. 
Walsh, J. R. (1993). China and the new geopolitics of central Asia. Asian Survey, 33, 272-284.

Weidmann, N. B. (2009). Geography as motivation and opportunity: Group concentration and ethnic conflict. Journal of Conflict Resolution, 53, 526-543.

Wimmer, A. (2002). Nationalist exclusion and ethnic conflict: Shadows of modernity. New York, NY: Cambridge University Press.

Wolff, S. (2013). Approaches to conflict resolution in divided societies: The many uses of territorial self-governance. International Journal on Minority and Group Rights, 20(1), 27-50.

Wucherpfennig, J., Metternich, N. W., Cederman, L.-E., \& Gleditsch, K. S. (2012). Ethnicity, the state, and the duration of civil war. World Politics, 64, 79-115.

Zimmermann, W. (1999). Origins of a catastrophe: Yugoslavia and its destroyers. New York, NY: Times Books.

Zinn, A. (2006). Economic integration and political separatism: Parallel trends or causally-linked processes? In D. R. Cameron, G. Ranis, \& A. Zinn (Eds.), Globalization and self-determination: Is the nation-state under siege? (pp. 233246). New York, NY: Routledge.

\section{Author Biographies}

David S. Siroky is an assistant professor of political science in the School of Politics and Global Studies at Arizona State University, where he is a core faculty member of the Center for Social Dynamics and Complexity and a faculty affiliate of the Center for the Study of Religion and Conflict and the Melikian Center for Russian, Eurasian and East European Studies. He received his $\mathrm{PhD}$ in political science and $\mathrm{MA}$ in economics from Duke University and was a postdoctoral fellow at Yale University. His research has appeared or is forthcoming in Comparative Sociology, Defence and Peace Economics, Democratization, Ethnopolitics, International Organization, Nationalities Papers, Polity, Post-Soviet Affairs, Security Studies, and Statistics Surveys.

John Cuffe is a PhD candidate in the Department of Political Science at University of California-Irvine. His research focuses on political parties, voting behavior, collective action, institutional design, and political methodology. 